\title{
Atrophoderma of Pasini and Pierini
}

*Ricardo Ruiz-Villaverde, ${ }^{1}$ Daniel Sánchez-Cano, ${ }^{2}$ Luis Salvador-Rodriguez, ${ }^{1}$ Carlos Cuenca-Barrales ${ }^{1}$

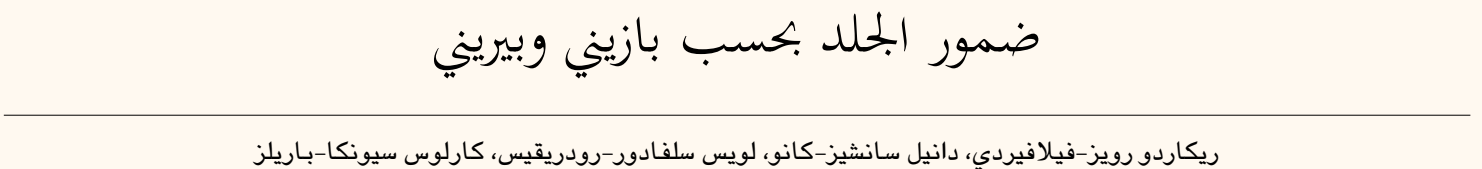

ريكاردو رويز-فيلافيردي، دانيل سانشيز-كانو، لويس سلفادور-رودريقيس، كارلوس سيونكا-باريلز

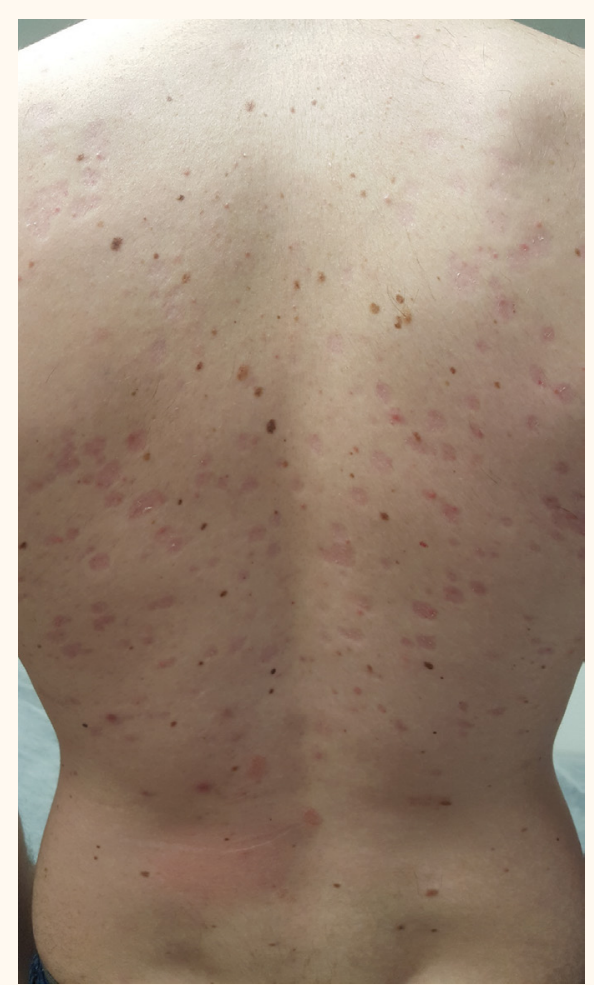

Figure 1: Photograph of multiple round, pink-coloured, atrophic plaques on the back of a 25-year-old male patient.

A

25-YEAR-OLD MAN WITH NO PERSONAL OR family history of interest attended the outpatient clinic of the Complejo Hospitalario de Granada, Granada, Spain, in 2017 with multiple, non-pruritic, atrophic, mildly indurated, brownish, erythematous patches on his back of one year's duration [Figure 1]. He denied any regular medication use or having had any previous conditions. There was no history of trauma preceding the appearance of the skin lesions. Routine laboratory tests were within normal limits, including a complete blood cell count, urinalysis, thyroid profile, protein electrophoresis and general biochemistry, antinuclear/extractable nuclear antibody and rheumatoid factor tests. Immunoglobulin $\mathrm{M}$ and $\mathrm{G}$ tests for Borrelia burgdorferi were negative.
A histopathological examination showed a normal epidermis with a slight mononuclear perivascular infiltrate in the papillary dermis and focal sclerosis with hyalinisation of the reticular dermis [Figure 2]. Narrowband ultraviolet B phototherapy was proposed as the first line of treatment; however, the patient refused to consent to the therapy.

\section{Comment}

Idiopathic atrophoderma of Pasini and Pierini (IAPP) is a rare, exclusively cutaneous condition which occurs most frequently in female patients, with a peak incidence in the second and third decades of life. ${ }^{1}$ Overall, fewer than 100 cases have been reported 


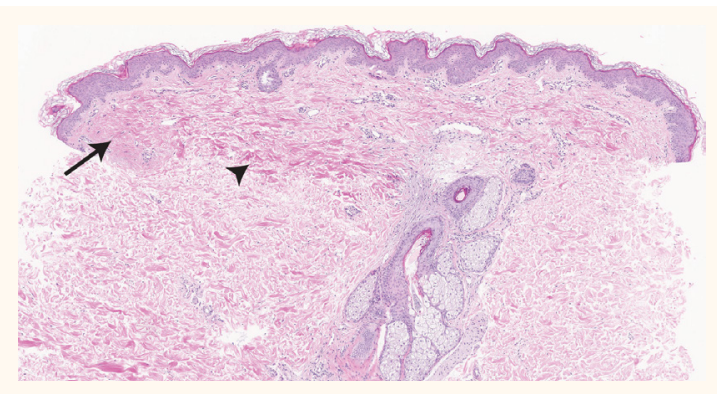

Figure 2: Haematoxylin and eosin stain at $x 4$ magnification showing a normal epidermis with discrete thinning of the upper dermis (arrow) and mild hyalinisation and sclerosis on the reticular dermis (arrowhead).

in the literature. ${ }^{2}$ The pathophysiology of this entity remains unknown and the role of Borrelia burgdorferi infections remains controversial. ${ }^{2}$ Some researchers believe that IAPP should be included as a manifestation of the spectrum of localised scleroderma. ${ }^{3}$ Some cases of familial IAPP have been described; however, a genetic link has not yet been confirmed. ${ }^{2}$

From a clinical point of view, IAPP lesions may present in various patterns (i.e. rounded, oval or circular) and may be single or multiple. ${ }^{3}$ The edges of the patches are usually well defined and multiple lesions, such as in the present case, have been described as having a 'swiss cheese' or 'footprints in the snow' appearance. The sites predominantly affected are the lower and upper extremities or the trunk and it is not unusual for the lesions to follow a zosteriform or blaschkoid pattern. ${ }^{3}$ The condition can cause pain, pruritus or even paresthesia.

The pathological findings of IAPP are variable. In many cases, no alterations can be observed in the epidermis or dermis. ${ }^{2,3}$ The most common finding is a thinning of the affected dermis and no quantitative or qualitative alterations have yet been reported on the appendages. ${ }^{3}$ Collagen changes can include atrophy, sclerosis, fragmentation and hyalinisation. ${ }^{2}$ Elastic fibre changes may be variable and reduction and fragmentation similar to that of anetoderma cases have been reported. ${ }^{4}$

The therapeutical approach to IAPP includes the use of different medications such as antibiotics (i.e. penicillin and tetracyclines) and hydroxychloroquine (with good response in cases with associated lupus) as well as topical treatments such as calcineurin inhibitors (although with variable responses)..$^{5-7}$ Treatment with a Q-switched Alexandrite laser has also been reported to result in the clinical improvement of hyperpigmented lesions. ${ }^{8}$

\section{References}

1. Batista CM, Lemos MO, Franceschi LE, Basilio CB, Reis CM. Case for diagnosis. An Bras Dermatol 2014; 89:671-3. doi: 10.1590/abd1806-4841.20142977.

2. González-Morán A, Martín-López R, Ramos ML, Román C, González-Asensio MP. [Idiopathic atrophoderma of Pasini and Pierini: Study of 4 cases]. Actas Dermosifiliogr 2005; 96:303-6. doi: 10.1016/S0001-7310(05)75059-6.

3. Arif T, Adil M, Amin SS, Ahmed M. Atrophoderma of Pasini and Pierini in a blaschkoid pattern. J Dtsch Dermatol Ges 2017; 15:663-4. doi: 10.1111/ddg.13198.

4. Saleh Z, Abbas O, Dahdah MI, Kibbi AG, Zaynoun S, Ghosn S. Atrophoderma of Pasini and Pierini: A clinical and histopathological study. J Cutan Pathol 2008; 35:1108-14. doi: 10.1111/j.1600-0560.2008.00986.x.

5. Lohrer R, Barran L, Kellnar S, Belohradsky BH. [Pasini and Pierini idiopathic and progressive atrophoderma in childhood]. Monatsschr Kinderheilkd 1986; 134:878-80.

6. Carter JD, Valeriano J, Vasey FB. Hydroxychloroquine as a treatment for atrophoderma of Pasini and Pierini. Int J Dermatol 2006; 45:1255-6. doi: 10.1111/j.1365-4632.2006.03021.x.

7. Pope E, Laxer RM. Diagnosis and management of morphea and lichen sclerosus and atrophicus in children. Pediatr Clin North Am 2014; 61:309-19. doi: 10.1016/j.pcl.2013.11.006.

8. Arpey CJ, Patel DS, Stone MS, Qiang-Shao J, Moore KC. Treatment of atrophoderma of Pasini and Pierini-associated hyperpigmentation with the Q-switched alexandrite laser: A clinical, histologic, and ultrastructural appraisal. Lasers Surg Med 2000; 27:206-12. doi: 10.1002/1096-9101(2000)27:3<206::AIDLSM2>3.0.CO;2-1. 